tion Hugo Haedrich, Ztschr. phys. Chem., 12, 496). There is doubtless, therefore, a close connection between the phenomena outlined above, and others depending on the degree of dissociation of the ions in solution. A study of the behavior of weaker solutions would doubtless lead to interesting results not brought out in the above experiments which were undertaken mainly to show the character and amount of precipitates formed. A discussion of the behavior of dilute solutions will follow.

Chicago, December, I894.

[CONTRIBUTIONS FROM THE CHEMICAL LABORATORY OF CASE SCHOOI, OF APPLIED SCIENCE. XXI.]

\title{
AN EXAMINATION OF THE ATMOSPHERE OF A LARGE MANUFACTURING CITY.'
}

\author{
By ChARLES F. MABERY. \\ Received December 23, 1894 .
}

HE composition of the atmosphere was determined in the
latter part of the last century by the classic researches of Priestley, Cavendish, Lavoisier, and others. These investigations were stimulated by Priestley's discovery of oxygen and the discovery of nitrogen by Rutherford. The proportion of nitrogen was first ascertained by Cavendish, and the precise quantitative composition was ascertained by Lavoisier, who repeated the celebrated experiment of Priestley, in which metallic mercury was heated for a long time in a confined volume of air to determine the quantity of gas absorbed and the residual nitrogen. The composition of the atmosphere with reference to the proportion of oxygen and nitrogen has since been frequently determined without showing any appreciable variation. In specimens of air collected from regions widely separated, Morley ( $\mathrm{Am}$. Chem. J., $2,276)$ determined with the utmost precision the proportion of oxygen and nitrogen without finding any appreciable variation.

The essential constituents of the atmosphere include oxygen, nitrogen, and carbon dioxide in constant proportions, nitrous and nitric acids, sulphurous and sulphuric acids, dust, soot, moisture, ammonia, and certain other constituents in variable

1 The experimental work of this paper was performed under my direction by Mr. Charles G. Snyder, and it formed the subject of his thesis for the Degree of Bachelor of Science. 
proportions depending upon atmospheric conditions and local influences. The allotropic form of oxygen, ozone, is an important constituent of the atmosphere, ancl probably also hydrogen dioxide.

With a population distributed over large areas, natural conditions are sufficient to keep the atmosphere in a nornal and healthful condition for the support of life. Such has been the condition in all civilized conntries until within the last thirty years the rapid accumulation of population near manufacturing centers and in cities, and the enormons consumption and incidental waste of coal has introduced important changes at these points. Not only are manufactories and other large establishments dependent for their maintenance upon the consumption of coal, but private habitations, which were formerly heated with wood as fuel with the production of a harmless smoke, now depend almost entirely upon coal. If hard coal is burned the smoke is not objectionable, but the escape of bituminous coal snoke from every household chimney in a densely populated city, together with dense volumes poured forth from large blocks is sufficient to keep the atmosphere in a questionable conclition in relation to health, comfort, and the deleterious effects on perishable formas of property. Under occasional condition of strong winds or rain, followed by clear weather, the city at mosphere is doubtless in a harmless condition; but it can not long remain unpolluted with immense volumes of sooty smoke poured forth from many chimneys.

Abroad, especially in England, the atnosphere of large cities, notably in manufacturing towns, has received considerable attention. Doubtless, on account of the rapid growth of American cities, and probably, also, because of an abundant supply of anthracite coal for cities too far removed from the regions of bituninous coal to render it profitable, the atmosphere of our cities has received little attention. But for cities situated near the soft coal regions, the question of atmospheric pollution has become of too serious moment to be long clisregarded.

To uncerstand the nature of smoke pollution it is necessary to refer to the composition of coal and to the products of its combustion under different conditions. Bituminous coal consists 
principally of compounds of carbon and hydrogen, or hydrocarbons with smaller proportions of nitrogen and sulphur compounds, and metallic compounds known as the ash when the coal is burned. So far as atmospheric pollution by coal smoke is concerned, the four elements, carbon, hydrogen, sulphur, and nitrogen, are the only constituents of coal that need to be considered.

In the combustion of coal with an adequate supply of air, under such conditions that the chemical reactions involved can be completed within the space allotted to combustion, the ultimate products are carbon dioxide, carbon monoxide, water, sulphurous acid, and ammonia. The less carbon monoxide the smoke contains the more efficient is the combustion; the sulphurous acid is usually converted, at least in part, into sulphuric acid by further oxidation in presence of moisture. It is only rarely, however, that the conditions requisite for complete combustion are maintained. The following features will be recognized as having an iniportant bearing upon the question of complete combustion: (I) A sufficient supply of air; (2) the combustion should not be forced too rapidly; (3) the temperature, especially at the moment of firing, must not be too low; (4) the size, form, and proportions of the space within which the combustion takes place must be suitably adapted. These are the principal points with which complete combustion is concerned, and they are evidently closely connected with the manner of firing and general care of the heating apparatus. In practice, these conditions are far from being realized; with an insufficient supply of air unequally distributed with reference to the fuel, especially with a low temperature, the carbon is only partially burned and the portion not consumed escapes in the form of soot.

The hydrogen burns first, and it has an important influence in maintaining the temperature sufficiently high for complete combustion of the carbon. If the coal contain considerable sulphur it must escape as sulphurous acid, or as sulphuric acid in complete combustion, or (as hydrogen sulphide) in incomplete combustion, and it would seem to be impossible to avoid deleterious effects of these acids in the atmosphere. No doubt sul- 
phuric acid should have some effect on such materials as bookbindings and delicate fabrics after collecting in dust during long periods of time, but the effect is greatly increased by the presence of soot, which, as we shall show, absorls the acid, and when it collects on any surface it occasions a greater accumulation of the acid than should occur in its absenct.

The state of the atmosphere in cities where bituminous coal is the principal fuel is dependent upon conditions of conbustion in which the chemical reactions are far from complete, with the result that the carbon escapes from the chimney in part as carbon dioxide, in part as carbon monoxide, and in a considerable part as soot. Under such conditions the sulphur is set free as a mixture of sulphuric and sulphurous acids and hydrogent sulphicle. The latter is readily shown by its effects on metals, especially on silver, which soon becones badly discolored on account of the formation of argentic sulphide. The soot ordinarily present in the atmosphere has a greasy consistency, readily recognized by subjecting it to pressure. It consists to a considerable extent of compounds of carbon and hydrogen known as hydrocarbons, which escape from the coal hy a process of destructive distillation under conditions somewhat similar to those in the distillation of coal in gas retorts. As mentioned above it carries with it the sulphur acids and ammonia, and it is highly destructive to regetable life, its action depending probably in part upon the formation on the leares and stems of a thin layer of tarry substance, which clogs the pores, thus interfering with the process of plant respiration. Sulphuric acid is highly destructive to the forms of organic conpounls of which regretation is composed and in soot it may accumulate to such an extent as to be injurious.

In complete combustion with no escape of soot, eren on a very large scale, as in manufactories, it is safe to assert that the natural conditions of the atmosplere may provent any undesirable effect from the products given off.

During the year I 889 the quantity of coal consumed in Cleveland included $1 I_{7}, I_{57}$ tons of anthracite and 924,602 tons of bituminous coal. Assuning one per cent. of sulphur in the latter, which is the average composition, 9,246 tons of sulplur 
were evolved in the combustion of the soft coal, equivalent to 28,305 tons of sulphuric acid, or nearly eighty tons a day. Without doubt this acid is tltimately neutralized in the atmosphere with the formation of ammonium or sodium salts, but directly it is sent forth it must exist chiefly as the free acid. In the evolution of considerable quantities of sulphur no doubt a portion remains for some time in the atmosphere in the form of sulphurous acid. In the city of Lille, France, as much as two cubic centimeters of sulphurous acid per liter has been found in the atmosphere and the rain water collected contained 0.022 gram per liter.

The ammonia evolved in the combustion of coal is not harmful. Indeed in combination with acids it is a normal constituent of the atmosphere. As one of the ultimate products of the decay of vegetable and animal bodies it is continually set free in this manner and it forms an essential element in the food of plants. The cycle of changes includes the evolution of nitrogen as ammonia from decaying organic bodies and the reabsorption as food by plants from the soils which receive it with the rain. Ordinarily natural conditions are sufficient to complete the transformation of the organic compounds during decay into ammonia in an equal distribution such as exists in the economy of nature. But when accumulation of animal or vegetable organic matter occurs at certain points, as in cities, the oxidizing forces of the atmosphere may not be sufficient to accomplish the vast amount of labor involved in decomposition and purification. On account of the extreme instability of the nitrogenous organic compounds these decompositions take place with great readiness in a limited supply of air but with the evolution of products that are a dangerous pollution in the atmosphere. The evidence of such changes in cities is not far to seek, especially if sanitary regulations are not rigidly enforced. Every stable, imperfect sewer connection, cesspool, sink drain, or offal receptacle readily contributes its share to the atmospheric pollution.

In chemical analysis the nitrogen in such products of decay is evolved as anmonia, and from its source in albumen and allied bodies it is known as albuminoid ammonia. Its presence in water or in the atmosphere may be accurately determined and it 
may indicate a dangerous condition since its formation is accompanied with, or perhaps is due to the agency of, organisms which are the means of germinating or spreading disease. As might be expected albuminoid ammonia is usually found in calm weather in the atmosphere of cities.

Ammonia has been mentioned as an ultimate product of decay of nitrogrenous organic nature; in the ordinary forms of decay and combustion, ammonia is the chief product, but it is usually attended in combustion with the formation, in small quantities, of nitrous and nitric acids, which may be considered as oxidation products. The extensive knowledge recently acquired, concerning the functions of organized germs, has shown that most forms of decay, and of purification as well, are dependent directly or indirectly upon their influence. Through the agency of the germ known as the niter ferment, for example, ammonia may be converted into nitric acid, and this change is constantly in progress where animal refuse accumulates, as in the vicinity of stables. The magnitude of these changes in nature will be appreciated when it is remembered chat most of the niter of commerce has been formed in this manner, either naturally, as in the niter beds in hot countries, or artificially, as in the niter plantations of Sweden. Although nitric acid is the uitimate product of such changes, as an intermediary product, nitrous acid is formed in combustion, and both these acids may be detected in the atmosphere where it is receiving, in large quantities, the products of combustion.

In certain cities, including Cleveland, whose rapid development in wealth and population has been dependent, to a large extent, upon their proximity to immense deposits of cheap fuel, the sooty condition of the atmosphere has rapidly increased within recent years until it has attracted much attention with the feeling that such a condition is not conducive either to personal comfort or to health.

Since, so far as we are informed, a thorough examination of the atmosphere in these cities has not been made, it seemed to us of sufficient interest to undertake a study of the atmosphere of Cleveland with especial reference to the constituents which have been described above, with determinations, so far as practicable, of the quantities present. 
As a means of ascertaining the quantity of soot deposited from the atmosphere, and also the amount of sulphuric acid removed from the atmosphere by snow, quantities of snow were collected for examination at the following localities which were assumed to represent an average condition of the city atmosphere,-McHenry St., Erie St., Covington St., and campus of the Case School of Applied Science; and the results, with certain data concerning the collection, are given in the following table:

\begin{tabular}{|c|c|c|c|}
\hline cation. & Date. & A rea. & $\begin{array}{l}\text { Weight } \mathrm{H}_{2} \mathrm{O} \\
\text { from snow } \\
\text { melted. } \\
\text { Grams. }\end{array}$ \\
\hline
\end{tabular}

(I) McHenry St., Feb. 19, 9 sq. by $I$ in. dp., $\quad 3583$

$0.3 \operatorname{II} 7$

(2) Erie St., Feb. 16, Col. on roof,

(3) Covington St., Newburg, Feb. I9, 3717

(4) C. S. A. S.,

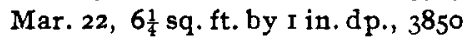

(5) Mar. 27, $7 \frac{1}{2}$ sq. ft. by $\frac{3}{4}$ in. dp., 2000

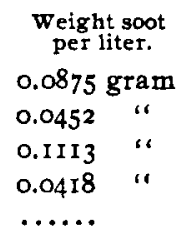

Weight $\mathrm{H}_{2} \mathrm{SO}$,
per liter.
0.0152 gram
0.0063 "،
0.0212 "
0.0139 "
0.0070 "

\begin{tabular}{|c|c|}
\hline \multicolumn{2}{|c|}{$\underset{\text { Weight } \mathrm{NH}_{8}}{\text { per liter. }}$} \\
\hline 0.00007 & gram \\
\hline $0.0000 \mathrm{I}$ & " \\
\hline 0.00012 & “ \\
\hline 0.000003 & " \\
\hline
\end{tabular}

These numbers are interesting in showing the large quantity of soot that falls from the atmosphere with the larger amounts collecting at certain points than at others. The quantities of sulphuric acid are large at all points, but nearly three times greater at Covington St., Newburg, near large establishments, than in the more open area near the Case School of Applied Science. The determinations of ammonia indicate an excessive amount at Covington St., and the least at the Case School of Applied Science.

The specific gravity of the water obtained by melting the snow was also determined:

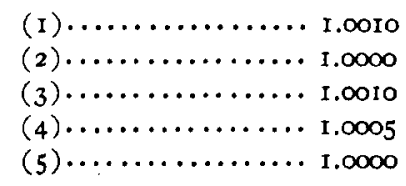


These specintens were collected after recent falls before the snow had heen contaminated to any considerahle extent. The duantity collected on the roof at lirie st. had fallen only a few hours previous to its collection.

On acconnt of the absorptive property of soot it seemed probable that it should retain a considerable quantity of sulphuric acid after it had fallen from the air. For definite proof a quantity of soot was collected on the wincow sills in the attic of the chennical laboratory, where it had been blown in under the window from the outside, it had probubly not been long in collecting. When moistened with water the soot gave a strong acid reaction on test paper, and andysis showed the presence of sulphuric acit.

1.3355 grams of the soot gave 0.0069 g gram barium sulphate, equivalent to r.9 i per cent. sulphuric acici.

Another determination of sulphuric acid was made in soot collected in the chimney of a house.

0.381 gram of this soot gave 0.0459 gram suphuric acid, which corresponds to $3 . \mathrm{i} /$ per cent. milphuric acid.

Sulphuric acid has invariahly ben found in testing soot collected in other places.

A noticeable characteristic of a sonty atmosphere and perhaps one of the most important. is the large quantity of soot deposited on the trunks and leaves of trees. In the absence of rain, soot must collect upon the leaves in sufficient quantity to interfere with their natural function of absorbing carbon dioxide. Since it appears that soot and duit absorb sulphuric acid, to a certain extent, from the atmosphere it seemed desirable to ascertain to what extent, if any, this acid collects on the bark of trees. At a point not far remored from manufacturing establishments quantities of bark were scraped from the trunk of a peach, a poplar, a cherry, a hickory, and an oak tree. Probably the kind of tree should not affect the deposition and absorption of acid except perhaps in the degree of roughness of the bark. Nevertheless there are decided differences in the amount of acia from the various sources. The following table gives the results of these determinations: 


\begin{tabular}{|c|c|c|c|c|c|c|}
\hline $\begin{array}{l}\text { Variety of } \\
\text { trees. }\end{array}$ & Area. & $\begin{array}{l}\text { Total Wt. } \\
\text { of bark. }\end{array}$ & $\begin{array}{l}\text { Weight } \\
\text { takenfor } \\
\text { analysis. }\end{array}$ & Wt. BasOt & Wt. $\mathrm{H}_{2} \mathrm{SO}_{4}$ & $\begin{array}{l}\text { Wt. } \mathrm{II}_{2} \mathrm{SO}_{4} \\
\text { per sq foot. }\end{array}$ \\
\hline Peach & $245.3 \mathrm{sq}$. in. & 17.5750 & 5.0008 & 0.0597 & $0.025 \mathrm{I}$ & $0.01+8$ \\
\hline Poplar & 280.0 & $3 \cdot 75.34$ & $3 \cdot 75,34$ & 0.0658 & 0.0277 & 0.01 .32 \\
\hline Cherry & 200.0 & 2.8886 & 29596 & 0.07 .32 & 0.0308 & 0.0221 \\
\hline Hickory & 400.0 & 3.1333 & $3 \cdot 1,3,33$ & 0.0467 & $0: 0196$ & $0.007 \mathrm{I}$ \\
\hline Oak & 400.0 & 6.7886 & 5.0297 & 0.0352 & 0.0148 & 0.0053 \\
\hline
\end{tabular}

In the order of the roughness of the bark the trees examined may be arranged as follows, with the peach as the least rough: peach, poplar, oak, hickory, cherry. Doubtless the deposition of soot containing acid upon the leaves is of even more serious consequence than upon the bark and the effects are clearly apparent on trees situated in the worst portions of a sooty atmosphere. The foliage of such trees exhibits an appearance of decay late in the summer months and the leaves fall early. We did not succeed in collecting specimens of leaves under suitable conditions to determine to what extent acid is retained on their surface.

Some attention has been given to the condition of the trees in such an atmosphere, but more especially with reference to the ravages of parasites that infest trees. In individual instances, no doubt, trees may be totally destroyed in this manner, but it is questionable whether the pernicious effects of a sooty atmosphere are not of more serious consequence on the trees as a whole. The corrosive action of an atmosphere impregnated with soot is daily manifest to the most ordinary ouservation. I have seen, in the country, nails withdrawn from a slingled roof seventy-five years after the shingles were laid, with the heads apparently unaffected, and the portion between the shingle and the board only slightly rusted away. In the atmosphere of a sooty city, as every one knows, after ten or fifteen years the nails on a roof are nearly consumed.

The effects of such an atmosphere on perishable property, such as certain forms of merchandise, are not so readily discernible, since this material is soon consumed by use. It is in libraries that the effects are most apparent. Fifteen years ago it was demonstrated by the late Professor W. R. Nichols that sulphuric acid is absorbed in bookbindings, and after some time the bindings begin to crumble; he found that the presence of the acid in deteriorated bindings may readily be shown. 
The samples of air for examination, were collected at the forlowing points, as fairly representing the different sections of the city.

(1) Campus of Case School of Applied Science, not far from the school buildings and those of Adelbert College. The line of the X. Y. St. Louis \& Chicago R. R. is one-eighth of a mile distant toward the south-east.

(2) McHenry St.; closely inhabited, numerous manufactories 700-1,000 feet distant; a line of foundries, steel works, etc. extends three niles along the lake front, one-half a mile distant toward the north from this point. Most of the solid particles of soot fall to the ground within one-fourth to one-half a mile from the source.

(3) Rockwell St.,; surrounded by large business blocks. The general condition of the atmosphere is bad on account of the soot, dust from the surrounding streets, and laxity in the enforcement of sanitary regulations.

(4) St. Clair St., near St. Lawrence; many large manufacturing establishments within 500 feet, on the lake shore, all using bituminous coal. When all are in operation, dense volunies of sooty smoke are sent forth into the atmosphere.

(5) West side; on the brow of the hill above the river near Pearl and Detroit Sts. Many loconotives pass below during the hour, and, on the river, tugs pass frequently. When the wind blows from the south-east, this locality is probably one of the worst in the city. The river itself doubtless aids the atmospheric pollution at this point since it is little better than an open sewer with a very sluggish current.

(6) South side, Jefferson St, a residence section with no factories near. In a north-easterly direction is a large ravine containing various kinds of decaying organic matter.

(7) Valley of the Cuyahoga, "Flats" ; a very large number of factories of all kinds together with slaughter houses, rendering establishments, etc. Noxious vapors and disagreeable odors from the river invest this entire locality. In clear weather the smoke ascends for the particular benefit of the inhabited districts on the neighboring bluffs. Circulation of the atmosphere is 
slow in damp weather and the impure atmosphere remains in the valley.

(8) Genessee Avenue, near Superior St.; a residence and farming district with no factories nearer than one-fourth of a mile.

(9) Mayfield, three miles outside of the city limits and six miles from the large manufacturing establishments of the city; a farming section with no barns nearer than one-fourth of a mile of the point where the collection of air was made.

(Io) Collinwood, three miles from the city limits, near the Lake Shore Railroad, where locomotives are constantly passing ; numerous barns close together, the nearest goo feet distant.

Numerous determinations of carbon dioxide at different points in sections of country widely separated have shown no appreciable variation. On the average it is not far from four parts in ro, 000 with a variation between three and five-tenths and four and five-tenths parts. Analyses of Cleveland air have shown some variation evidently depending upon the particular conditions at the point where the collection was made:

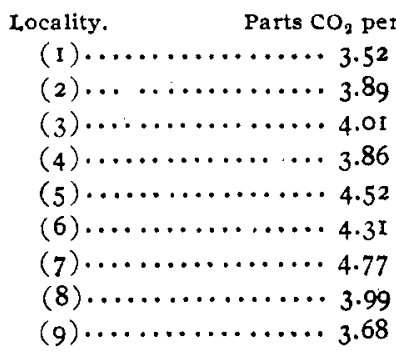

We have attached no particular importance to the determination of carbon dioxide in connection with the principal object of this examination. The following numbers represent the quantity usually present in a city atmosphere :

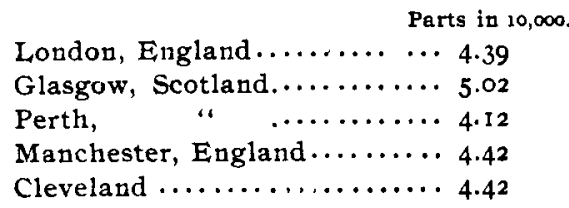

In determining soot in the atmosphere a measured volume of 
air was drawn through a piece of combustion tubing partly filled with ignited asbestos and the carbon was determined by ignition, and absorption of the carbon dioxide as in ordinary conbustions. The weights given in the following table are probably somewhat too low, since the soot is doubtless composed, for the most part, of hydrocarbons :

\begin{tabular}{|c|c|c|c|c|c|c|c|}
\hline \multirow{3}{*}{$\begin{array}{l}\text { Locality. } \\
\qquad \begin{array}{l}\text { (1) } \\
\text { (2) }\end{array}\end{array}$} & \multirow{3}{*}{$\begin{array}{c}\text { Weather } \\
\text { Clear } \\
\text {, }\end{array}$} & \multicolumn{2}{|c|}{$\begin{array}{l}\text { Vol of air } \\
\text { to and } 76 \mathrm{~cm} . \\
\text { Liters. }\end{array}$} & \multicolumn{2}{|c|}{$\mathrm{w}^{*}$ t. $\mathrm{CO}_{\mathrm{g}}$} & \multicolumn{2}{|c|}{$\begin{array}{l}\text { Weight soot } \\
\text { in I, } 000,000 \\
\text { cubic meters. }\end{array}$} \\
\hline & & $N$ & 94.0 & $0.0034 \mathrm{~g}$ & ram & 9,875 & grams \\
\hline & & S. W. & 70.2 & 0.0017 & $" i$ & 6,609 & $\because$ \\
\hline (3) & ' & N. W. & 88.2 & $0.005^{1}$ & “" & I 5,773 & $"$ \\
\hline (5) & $"$ & S. W. & 92.5 & 0.0042 & $"$ & I 2,386 & " \\
\hline (5) & "' & N. W. & 88.7 & 0.0005 & " & $\mathrm{I}, 5,38$ & “ \\
\hline (6) & Cloudy & w. & 89.3 & 0.0054 & " & 16,491 & " \\
\hline (6) & Clear & w. & 91.3 & 0.0027 & “" & 8,065 & " \\
\hline (8) & " & N. W. & 94.3 & 0.0053 & “ & 15,330 & “" \\
\hline (8) & $"$ & N. W. & 77.9 & 0.0140 & " & 39,906 & ، \\
\hline
\end{tabular}

A clearer idea may be gained of the quantities of soot given above, if it is understood that $1,000,000$ cubic meters is equivalent to the quantity of air contained within a space one mile square and a little more than one and one-fourth feet deep, and that the quantity of carbon, 39.664 grams calculated from analysis of the air collected at Genessee Ave., is equivalent to approximately 8.7 pounds. This very high result has no direct bearing on the quantity of soot in the atmosphere at this point, since it may be attributed to a high wind which filled the air with dust while the experiment was in progress. The air was collected at McHenry St., seven hours after rain had fallen. In certain conditions of the atmosphere frequently observed, there can be no doubt that the quantity of organic dust in suspension is very much larger than is represented by the values given above. The variable proportion of carbonaceous matter in the city air is shown in the duplicate samples collected at the West Side, the South Side, and Genessee Avenue. With the wind blowing from the north-west at the West Side the air is very clear, but in the direction of the south-east, as mentioned above, this section is in the direct line of the smoke from the river valley. Evidently these determinations serve to indicate merely the quantity in suspension in the air examined; but since the soot is rapidly 
deposited, these values are, in no sense, a measure of the quantity escaping into the atmosphere.

In determining sulphur in the atmosphere in the form of sulphuric acid, a measured volume of air was drawn through a large $U$ tube containing a solution of sodium hydroxide and broken glass, after passing through ignited asbestos. The alkaline solution was acidified with hydrochloric acid, oxidized with bromine, and the sulphuric acid precipitated with barium chloride. The quantities obtained are given in the following table:

Date. Locality. Weather. Wind. Velocity of air.

(I) Apr. 9, A. M.

C. S. A. S.

Clear N. E.

53.9 liters

(2) " 9, P.M.

(3) "I I3,

(4) " 19 ,

(5) June I3,

(6) Apr. 23 ,

(7) 624 ,

(8) $\because 27$,

(9) June 29,

(Io) Apr. 30,

(I I) May I,

(I2) " 7 ,

(I3) “ I5,

(14) June 26 ,

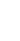

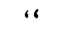

"Variable

" N.E. 6.25 miles IOI.5 "

McHenry St. Cloudy S. W. 3.7 " 27.3 "

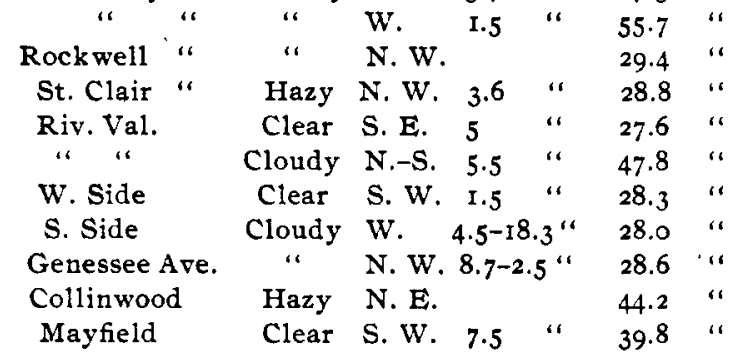

\begin{tabular}{|c|c|}
\hline Locality. Weight Baso 4 & $\begin{array}{r}\text { Grams } \mathrm{H}_{\gamma} \mathrm{SC} \\
\mathrm{I}, \infty \infty, \infty 00 \mathrm{Cu}\end{array}$ \\
\hline (I) $\ldots \ldots \ldots \ldots \ldots .0 .0030$ & 23414 \\
\hline (2) $\ldots \ldots \ldots \ldots \ldots \ldots .0028$ & 21859 \\
\hline$(3) \ldots \ldots \ldots \ldots \ldots .0053$ & 20178 \\
\hline$(4) \ldots \ldots \ldots \ldots \ldots .0027$ & 42156 \\
\hline$(5) \ldots \ldots \ldots \ldots \ldots, 0.0022$ & I 66 I 5 \\
\hline$(6) \ldots \ldots \ldots \ldots \ldots .0033$ & $4780 \mathrm{r}$ \\
\hline$(7) \ldots \ldots \ldots \ldots \ldots .001$ & 16142 \\
\hline$(8) \ldots \ldots \ldots \ldots \ldots \ldots . \ldots \ldots 33$ & 50629 \\
\hline (9) $\ldots \ldots \ldots \ldots \ldots .0 .0033$ & 29014 \\
\hline (10) $\ldots \ldots \ldots \ldots \ldots .0 .0057$ & 56828 \\
\hline (II) $\ldots \ldots \ldots \ldots \ldots .0042$ & 63289 \\
\hline$(12) \ldots \ldots \ldots \ldots \ldots .0023$ & 33989 \\
\hline$(13) \ldots \ldots \ldots \ldots \ldots .0000$ & $\cdots$ \\
\hline$(14) \ldots \ldots \ldots \ldots \ldots .0007$ & 7392 \\
\hline
\end{tabular}

The variation in the quantity of sulphuric acid in the atmosphere is shown in the duplicate determinations at McHenry St., and the river valley, made at different dates. A negative result 
at Collinwood is, perhaps, what might be expected in country air under certain conditions. And yet it seems that it was possible for sulphuric acid to be carried as far as Mayfield. It would be interesting to examine the atmosphere at different distances outside the city to ascertain how far the influence of the city air extends.

The following weights in grams of sulphuric acid in $\mathrm{I}, 000,000$ cubic meters, have been found in the atmosphere of cities in England:

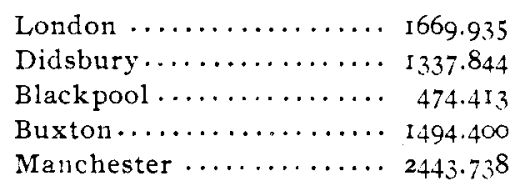

As already explained, sulphur sent forth into the atmosphere from the combustion of coal may escape complete oxidation and appear in part as hydrogen sulphide and in part as sulphurous acid. In testing for sulphurous acid in the atmosphere neat the Case School of Applied Science, a measured volume of air was drawn through the alkaline solution for absorption, and in one portion the sulphuric acid was precipitated with barium chloride. The weight of barium sulphate corresponded to $20,276.36$ grams of sulphuric acid in $1,000,000$ cubic meters. To the remaining portion of the solution used for absorption bromine was added for oxidation, and the solution precipitated with barium chloride. The difference in weights corresponded to 33,033. I grams of sulphuric acid in $I, 000,000$ cubic meters. In further confirmation of the presence of both sulphurous and sulphuric acids, another determination was made on the "Flats," near the Central viaduct, on an exceptionally clear day. In eighty-six liters of air aspirated, the total weight of barium sulphate, after oxidation, corresponded to $0.0058 \mathrm{gram}$ barium sulphate, and the weight of barium sulphate before oxidationwas equivalent to $0.0028 \mathrm{gram}$ barium sulphate, the difference, $0.003 \mathrm{I}$, representing the sulphurous acid in the total volume of air aspirated. The quantity of sulphuric acid present was, therefore, represented by I I,85 I grams, and the sulphurous acid by 12,5 I 2.6 grans in $1,000,000$ cubic meters.

In the atmosphere of other cities, notably in Manchester, 
England, and Lille, France, sulphurous acid has been determined, and it is probable that it may always be detected in the atmosphere where it receives large quantities of smoke from the combustion of coal.

The presence of ammonia as a normal constituent of the atmosphere has already been mentioned, and under ordinary conditions it does not collect in sufficient quantity to be injurious. Nevertheless, it seemed of interest to ascertain to what extent this constituent collects in an atmosphere contaminated with soot. In collecting ammonia, a definite volume of air was drawn through a dilute solution of hydrochloric acid, and both free and albuminoid ammonia were determined by the methods ordinarily employed in water analysis. After the free ammonia was distilled the residual solution was oxidized with alkaline permanganate until there was no further evolution of ammonia, and both sets of distillates nesslerized. The following tables give the quantity of free and albuminoid ammonia from the quantity of air aspirated in each locality and the state of the weather.

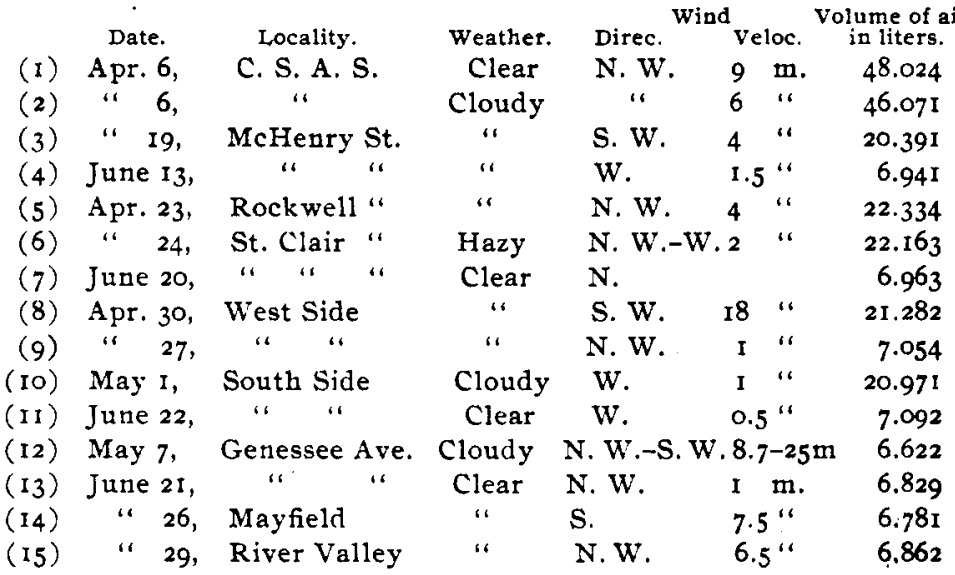

Total free $\mathrm{NH}_{3}$.

(2)

(3) 0.0000005 I

Total Albuminoid $\mathrm{NH}_{\mathbf{3}}$. 0.00000490 $0.000007 \mathrm{I}$ 0.00002 I 80 0.0000045 0.0000113 0.0000021 0.00000210

(5) 0.00000780

(6) 0.00002330 0.0000035 0.0000051
Free $\mathrm{NH}_{3}$ in I,000,000 cu. met. 106. Io grams 106.35 1070.20 302.50 " 357.20 " I051.10
Albuminoid $\mathrm{NH}_{3}$ in I, $000, \infty \infty$ cu. met. 147.84 grams 97.67 $\mathbf{5 5 7 . 5 0}$ 298.90 " 158.90 " 230.10 . " 


\begin{tabular}{|c|c|c|c|c|c|c|}
\hline \multirow{3}{*}{$\begin{array}{l}(7) \\
(8)\end{array}$} & \multirow{3}{*}{$\begin{array}{c}\begin{array}{c}\text { Total } \\
\text { free NH, }\end{array} \\
0.0000014 \\
0.0000082\end{array}$} & \multirow{3}{*}{$\begin{array}{c}\text { Total } \\
\text { Albuminoid } \mathrm{NH}_{9} . \\
0.0000023 \\
0.0000027\end{array}$} & \multicolumn{2}{|c|}{$\begin{array}{c}\text { Free } \mathrm{NH}_{3} \text { in } \\
1,000,000 \text { cu. met. }\end{array}$} & \multirow{2}{*}{\multicolumn{2}{|c|}{$\begin{array}{l}\text { Albuminoid } \mathrm{NH}_{3} \text { in } \\
3,00, \infty 00 \mathrm{cu} \text { met. } \\
329.1 \text { grams. }\end{array}$}} \\
\hline & & & 198.7 & ". & & \\
\hline & & & $385 \cdot 5$ & ، & 173.8 & $" 1$ \\
\hline (9) & 0.0000059 & 0.0000030 & 836.9 & " & 430.9 & " \\
\hline (10) & 0.0000169 & 0.0000043 & 806.4 & " & 202.5 & “ \\
\hline (II) & 0.0000015 & 0.0000007 & 214.5 & “" & 100.6 & ‘ \\
\hline (12) & 0.0000086 & 0.0000031 & 1373.0 & “ & 489.5 & “" \\
\hline (13) & 0.0000030 & 0.0000034 & 440.6 & “ & 492.0 & “" \\
\hline (14) & 0.0000035 & 0.0000019 & 510.2 & “ & 282.8 & " \\
\hline (15) & 0.0000054 & 0,0000010 & 787.7 & " & 150.1 & " \\
\hline
\end{tabular}

We have found on record but few determinations of free and albuminoid ammonia, but similar determinations have been made in certain cities abroad, the results of which afford an interesting comparison with those we have obtained.

\begin{tabular}{|c|c|}
\hline $\begin{array}{c}\text { Grams free } \mathrm{NH}_{3} \text { in } \\
\mathrm{I}, 000,000 \text { cu. met. }\end{array}$ & $\begin{array}{l}\text { Grams albuminoid } \mathrm{NH}_{s} \\
\text { in } \mathrm{I}, 00,000 \mathrm{cu} \text {. met. }\end{array}$ \\
\hline London ..........6. 61.286 & I50.9I 9 \\
\hline Glasgow........... $7^{8.196}$ & 304.974 \\
\hline Innellan.......... $52.28 \mathrm{I}$ & 137.832 \\
\hline
\end{tabular}

These numbers represent nuch smaller quantities of albuminoid ammonia, and still smaller quantities of free ammonia than appear in the results of our determinations.

It has long been known that nitrous acid and nitric acid are contained in the products of combustion from fuels containing nitrogen as most fuels do. These acids represent a more advanced stage of oxidation than ammonia; they are derived to a certain extent, it may be, from the oxidation of atmospheric nitrogen; and they may also be detected in the products of respiration. Ammonium nitrate may be found in dew and it seems to be present in larger quantities in spring than in summer and more at night than during the day. These acids are, therefore, normal constituents of the atmosphere under natural conditions, and the minute quantities usually present can not be considered harmful.

In testing for nitric acid we used as an indicator phenolsulphonic acid prepared by dissolving phenol in concentrated sulphuric acid and for comparison, a solution of potassium nitrate in which one cc. contained 0.00000 I gram nitrogen. For nitrous acid, sulphanilic acid and naphthylamine hydrochloride were used as indicators with a solution of sodium nitrite, in which one cc. contained 0.000001 gram nitrogen as a means of com- 
parison. A measured volume of air was drawn through a solution of sodium hydroxide prepared from metallic sodium, and definite quantities of this solution were used in each determination.

The following tables give the quantities of nitrous and nitric acids found in experiments conducted at different localities with other data of the collection:

Nitrous ACID.

\begin{tabular}{|c|c|c|c|}
\hline Date. & Place. & Weat & $\begin{array}{l}\text { Grams HNC } \\
I, \infty \infty, \infty \infty \text { cub. }\end{array}$ \\
\hline Apr. I7, & C. S. A. S. & Clear & W. N. E............ 6.767 \\
\hline May II, & “ & & w. N. w.............. \\
\hline July 2, & " & Cloudy & Calm................. \\
\hline 1 I9, & McHenry St. & "، & $\ldots \ldots \ldots \ldots$ IIg.27 \\
\hline & a & Clear & . . . . . . . 73.97 \\
\hline Ap & Rockwell " & Cloudy & $m p \cdots \cdots \cdots \cdots \cdots \cdots 5^{2.7}$ \\
\hline June & ، & Clear & w. N. w........... $8.8_{5}$ \\
\hline Apr. & St. Clair " & " & N. W........... I 26.6 \\
\hline June 20 , & "6 & " & W. N................ 355.50 \\
\hline June 29, & River Valley & Cloudy & $\ldots \ldots \ldots \ldots 0.60$ \\
\hline May 4, & West Side & Clear & $\ldots \quad 15.20$ \\
\hline 27 & & " & N. W............ 19.94 \\
\hline June 22, & South Side & ، & …...... 1.23 \\
\hline May & Genessee Ave & " & $\ldots \ldots \ldots$ \\
\hline Jun & & ، & $\cdots \ldots \ldots \ldots$ \\
\hline $\mathrm{Ma}$ & Collinwood & $\begin{array}{l}\text { Cloudy } \\
\text { NITRIC }\end{array}$ & Calm.... \\
\hline & & & \\
\hline
\end{tabular}

April 17,

May II,

April I9,

June I3,

April 24,

June 20,

April 27,

June 27,

April 30,

May 4 ,

June 27,

May I,

June 22,

May 7 ,

June 2I,

May I5,

C. S. A. S............. 674.5

NITRIC ACID.

June 16 ,

" $\quad$................ 560.0

McHenry St............. 703.8

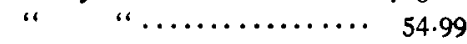

St. Clair St............. 520.5

" " . ............. 144.0

River Valley. ............. 704.0

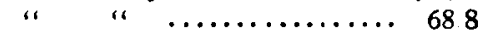

West Side $\ldots \ldots \ldots \ldots \ldots \ldots$....... 1063.6

" " $\quad \ldots \ldots \ldots \ldots \ldots \ldots . . \ldots \ldots 67.6$

" " $"$ " $\quad \ldots \ldots \ldots \ldots \ldots \ldots .66 .9$

South Side............. $6 r .8$

" " $\quad \ldots \ldots \ldots \ldots \ldots \ldots$ 153.8

Genessee Avenue $\ldots \ldots \ldots \ldots \ldots 333.6$

" " $\quad \ldots \ldots \ldots \ldots, 129.4$

Collinwood $\ldots \ldots \ldots \ldots \ldots \ldots, 424.0$

June $26, \quad$ Mayfield ............... 44.5

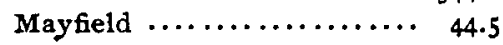


The variation in the proportion of both nitrous and nitric acids under different conditions is very marked, as shown in the samples of air collected in the rivervalley, the West Side, and McHenry St.

From the results of this examination it is evident that a city atmosphere, contaminated by the universal consumption of bituminous coal, where no efforts are made to prevent the escape of soot, soon reaches a stage in which it is destructive to property and not conducive to health. In this respect the atmosphere of Cleveland is, doubtless, no worse than that of other cities, and, perhaps, in a better condition than some that use the same fuel. Under the usual conditions of life in cities, sanitary regulations require careful attention and constant supervision.

\section{A NEW FORM OF WATER-OVEN AND STILL.'}

By LeWIS WILliam HoffmanN AND RoBert W. Hochstetter, Received November 8,1894

In the use of the ordinary form of water-oven we have been impressed with the fact that there are several disadvantages connected with that form of this apparatus. For instance, there is the necessity for refilling it from time to time, with the consequent fall in temperature and loss of time; there is the waste of stean which might be condensed to the always-useful distilled water, and we have had trouble in obtaining a constant temperature of $100^{\circ} \mathrm{C}$. To obviate these difficulties we have devised the combined oven and still which we describe here-a piece of apparatus that has an automatic feed, a worm for condensing the steam and an arrangement of the heating surface so as to provide for perfect circulation and quiet boiling, with steady and abundant generation of steam.

The combination of still and oven is not new, for in the April, 1892, number of the Journal of Analytical and Applied Chemistry, Herbert M. Hill describes such a piece of apparatus in use in the BuffaloUniversity laboratory. Except for the combination it bears little resemblance to our apparatus.

In our form of apparatus, the heating surface consists largely of a series of pipes, connected with water boxes at each end.

1 kead before the Cincinuati section, October 15, 1894. 